\title{
EKSTRAKSI SENYAWA FENOLIK DARI LIMBAH KULIT KACANG TANAH (Arachis hypogea L) SEBAGAI ANTIOKSIDAN ALAMI
}

\author{
Yosophine Sulistyani, Steven Andrianto, Nani Indraswati, Aning Ayucitra* \\ Kelompok Keahlian Rekayasa Proses, Jurusan Teknik Kimia, Fakultas Teknik \\ Universitas Katolik Widya Mandala \\ Jalan Kalijudan 37, Surabaya 60114 \\ E-mail: aayucitra@yahoo.com
}

\begin{abstract}
Abstrak
Kulit kacang mengandung senyawa fenolik yang bersifat antioksidan. Kandungan polifenol dalam kulit kacang sekitar 3,34-7,13\%, oleh sebab itu kulit kacang tanah dapat diolah lebih lanjut sebagai sumber antioksidan alami. Antioksidan dapat menghambat proses kerusakan bahan pangan yang disebabkan oleh proses oksidasi dan mampu menangkal radikal bebas. Tujuan dari penelitian ini adalah untuk mempelajari pengaruh suhu dan waktu ekstraksi terhadap perolehan, kadar senyawa fenolik dan aktivitas antioksidan dalam proses ekstraksi senyawa fenolik dari kulit kacang tanah. Suhu dan waktu ekstraksi yang optimum ditentukan dari perolehan senyawa fenolik yang terbesar. Dalam penelitian ini, aktivitas antioksidan dari ekstrak dibandingkan terhadap aktivitas antioksidan sintetis TBHQ (tertiary butylhydroquinone). Berdasarkan hasil penelitian didapatkan bahwa semakin tinggi suhu dan semakin lama waktu ekstraksi maka dihasilkan perolehan ekstrak, kadar senyawa fenolik, dan perolehan fenolik yang semakin tinggi. Perolehan akan meningkat sampai batas tertentu kemudian mengalami penurunan. Ekstrak kulit kacang dengan perolehan fenolik terbesar $(0,6534 \mathrm{~g} \mathrm{GAE} / 100 \mathrm{~g}$ kulit kacang) diperoleh pada proses ekstraksi dengan kondisi suhu ekstraksi $70{ }^{\circ} \mathrm{C}$ dan waktu ekstraksi 105 menit. Aktivitas antioksidan dari ekstrak tersebut hampir menyamai aktivitas antioksidan sintetis TBHQ yaitu sebesar 97,98\%.
\end{abstract}

Kata kunci: kulit kacang tanah, antioksidan, senyawa fenolik

\begin{abstract}
Peanut shell contains phenolic compounds which may be used as natural antioxidants. The content of polyphenols in peanut shells is around 3.34-7.13\%. Antioxidants may inhibit the process of food damage caused by oxidation since they can counteract the free radicals. The purpose of this research was to study the effect of extraction temperature and extraction time on the yield, total phenolic content (TPC), and antioxidant activity of extracts. Antioxidant activity of extracts were compared to those of synthetic antioxidant TBHQ (tertiary butylhydroquinone). The results showed that the higher the temperature and the longer time of extraction results in the higher yield of extract, phenolic content, and also yield of phenolic. The yield increased to a certain level and then decreased. The highest yield of phenolic ( $0.6534 \mathrm{~g} \mathrm{GAE} / 100 \mathrm{~g}$ peanut shell) was obtained at extraction temperature of 70 ${ }^{\circ} \mathrm{C}$ for 105 minutes. The antioxidant activity of extract also comparable to those of synthetic antioxidant TBHQ which was $97.98 \%$.
\end{abstract}

Keywords: peanut shell, antioxidants, phenolic compounds

*korespondensi 


\section{Pendahuluan}

Saat ini, usaha pertanian memegang peranan penting untuk menghasilkan berbagai sumber makanan seperti kacang tanah (Arachis hypogea L). Di Indonesia terdapat banyak industri kacang tanah baik yang berskala besar, menengah maupun kecil, yang menghasilkan berbagai produk olahan berkualitas. Limbah yang umumnya dihasilkan dari industri kacang berupa kulit kacang. Produk kacang yang dihasilkan di Indonesia relatif besar. Penggunaan kacang tanah pada industri makanan berbahan dasar kacang tanah mampu mencakup hingga 1,25 ton biji kacang tanah per hari, sehingga dari jumlah tersebut dihasilkan limbah kulit kacang tanah dalam jumlah yang besar pula. Pemanfaatan kulit kacang tanah masih terbatas sebagai makanan ternak, padahal kulit kacang tanah mengandung senyawa fenolik yang bersifat antioksidan (Wee dkk., 2007). Kulit kacang mengandung polifenol sekitar 3,34-7,13\% (Kikuzaki dkk., 2002). Oleh karena itu, dibutuhkan upaya lebih lanjut untuk menjadikan kulit kacang sebagai bahan yang bermanfaat dan memiliki nilai ekonomis lebih tinggi, salah satunya adalah dengan mengambil kandungan senyawa fenolik yang terdapat di dalamnya untuk dimanfaatkan sebagai antioksidan alami.

Dalam rangka menghambat proses kerusakan bahan pangan yang disebabkan oleh proses oksidasi, terutama yang mengandung protein dan lemak, banyak industri pangan menggunakan antioksidan sintetis seperti BHA (Butylated Hydroxyanisol), BHT (Butylated Hydroxytoluene) dan TBHQ (Tertiary Butyl Hidroquinone). Antioksidan sintetis ini sering digunakan untuk bahan makanan semi basah seperti tahu, daging, mie, ikan serta minyak atau lemak sebagai bahan anti tengik dan tahan lama. Namun dewasa ini pemakaian antioksidan sintetis mulai mendapat respon negatif karena berpotensi menyebabkan kanker dalam tubuh (Iqbal dkk., 2005; Sultana dkk., 2007). Antioksidan alami pada tumbuhan umumnya berupa senyawa fenolik atau polifenol yang dapat berupa golongan flavonoid, turunan asam sinamat, kumarin, tokoferol, dan asam-asam organik polifungsional. Senyawa antioksidan alami polifenolik ini adalah multifungsional dan dapat beraksi sebagai pereduksi, penangkap radikal bebas, pengkelat logam, dan peredam terbentuknya singlet oksigen $\left({ }^{1} \mathrm{O}_{2}\right)$. Hal ini mendorong semakin banyak dilakukan eksplorasi bahan alam sebagai sumber antioksidan (Halliwell dan Gutteridge, 2000; Kikuzaki dkk., 2002).

Pada penelitian ini, senyawa fenolik yang terdapat di dalam kulit kacang tanah dan berpotensi sebagai sumber antioksidan alami, diekstrak menggunakan pelarut etanol. Pelarut etanol ini digunakan untuk ekstraksi karena tergolong murah, mudah diperoleh, dan relatif lebih aman untuk kesehatan dibandingkan dengan pelarut organik lain (Dengi dan Mulyandasari, 2009). Pengaruh suhu dan waktu ekstraksi terhadap total fenolik yang terekstrak dari kulit kulit kacang tanah dipelajari. Selain itu, dipelajari juga aktivitas antioksidan dari ekstrak kulit kacang tanah dan dibandingkan dengan antioksidan sintetis TBHQ.

\section{Metodologi \\ 2.1 Bahan dan Alat}

Bahan yang digunakan meliputi limbah kulit kacang tanah yang diperoleh dari daerah Kudus-Jawa Tengah, etanol 96\% teknis, reagen Folin-Ciocalteu (Merck M-9001), DPPH (2,2-diphenyl-1-pikrylhydrazyl, Sigma Aldrich Chemistry), metanol p.a., TBHQ, dan bahan kimia lain yang diperoleh dari penyedia bahan kimia di Surabaya dan dipergunakan langsung tanpa pemrosesan lebih lanjut. Alat yang digunakan dalam penelitian ini meliputi rangkaian alat ekstraksi (Gambar 1), Moisture Analyzer (MC Ohauss MB35 HalogenSwitzerland), oven vakum (Vacuum Lab-Line, USA), dan spektrofotometer (Shimadzu UVVIS 1201).

\subsection{Prosedur Penelitian}

Prosedur penelitian dibagi menjadi tiga tahap, yaitu: 1) persiapan serbuk kulit kacang tanah, 2) proses ekstraksi kulit kacang tanah, dan 3) analisis hasil ekstrak kulit kacang tanah yang meliputi penentuan perolehan, uji Total Phenolic Content (TPC) dengan metode Folin-Ciocalteu Micro Test Method, dan uji aktivitas antioksidan dengan metode serapan radikal DPPH. Proses ekstraksi kulit kacang tanah dilakukan dengan menggunakan pelarut etanol karena pelarut etanol bersifat polar sehingga mampu mengekstrak komponen antioksidan (senyawa fenolik) yang terdapat dalam kulit kacang tanah yang umumnya bersifat polar (Sultana dkk., 2007). Selain itu, etanol bersifat lebih aman untuk kesehatan dibandingkan metanol (Pokorny dkk., 2001). 


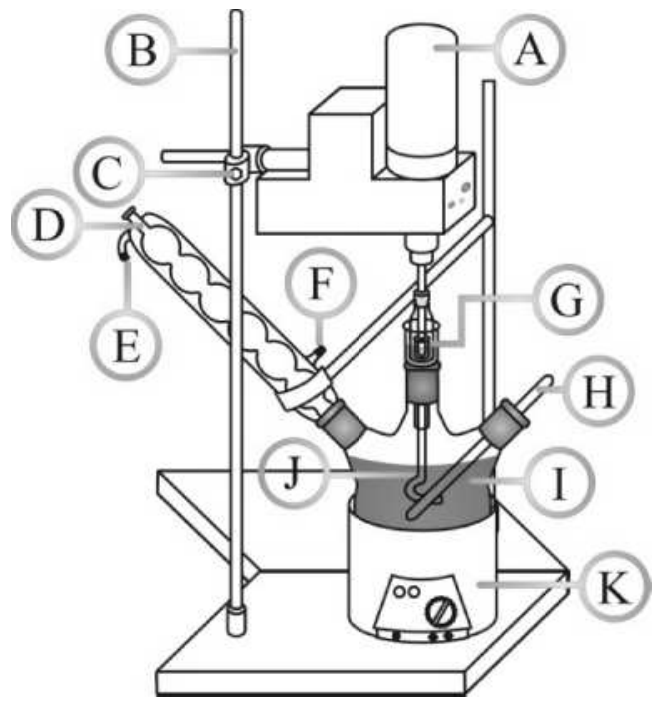

Keterangan :

A. Motor Pengaduk

B. Statif

C. Klem

D. Bulb Condenser

E. Air pendingin keluar

F. Air pendingin masuk

G. Minyak

H. Termometer

I. Labu leher tiga

J. Pengaduk merkuri

K. Jaket pemanas

\section{Gambar 1. Rangkaian alat ekstraksi}

Proses ekstraksi berlangsung pada suhu 30, 50 , dan $70{ }^{\circ} \mathrm{C}$ dengan variasi waktu $15,30,45$, $60,75,90,105,120$, dan 135 menit sehingga dapat dipelajari pengaruhnya terhadap total fenolik yang terekstrak dari kulit kacang tanah.

Pada tahap pertama, yang merupakan tahap persiapan bahan baku, kulit kacang tanah dikeringkan dengan menggunakan oven, kemudian dihancurkan dengan grinder hingga menjadi serbuk berukuran 20-80 mesh. Analisis kadar air serbuk kulit kacang dilakukan dengan alat moisture analyzer, sedangkan kadar abunya dianalisis mengikuti prosedur "Official Methods and Recommended Practices of the Americal Oil and Chemical Society" (AOACS, 2000). Hasil analisis bahan baku serbuk kulit kacang adalah sebagai berikut: kadar abu sebesar 3,81\% dan kadar air sebesar 13,45\%.

Tahap kedua dan ketiga meliputi proses ekstraksi serbuk kulit kacang dan analisis hasil ekstrak kulit kacang tanah. Serbuk kulit kacang tanah sebanyak $10 \mathrm{~g}$ diekstraksi dengan $100 \mathrm{~mL}$ pelarut etanol 96\% dengan kecepatan pengadukan $250 \mathrm{rpm}$. Ekstraksi dilakukan pada suhu $30{ }^{\circ} \mathrm{C}$ serta waktu ekstraksi 15 menit. Campuran didinginkan sampai mencapai suhu kamar kemudian disaring dengan kertas Whatman no. 42. Filtrat dipekatkan dalam oven vakum pada suhu $60{ }^{\circ} \mathrm{C}$ sehingga diperoleh ekstrak kulit kacang tanah. Ekstrak lalu ditimbang untuk menentukan perolehan ekstrak dan juga dianalisis Total Phenolic Content (TPC). Langkah tersebut diulang untuk variasi suhu
50 dan $70{ }^{\circ} \mathrm{C}$, serta waktu ekstraksi hingga 135 menit dengan interval waktu 15 menit, sampai diperoleh suhu dan waktu optimum yang memberikan perolehan senyawa fenolik dari ekstrak kulit kacang yang terbesar. Ekstrak dengan TPC terbesar pada masingmasing variasi suhu ekstraksi dianalisis aktivitas antioksidannya dengan metode DPPH yang dinyatakan dalam scavenging activity atau aktivitas pengkhelatan.

Perhitungan perolehan ekstrak kulit kacang tanah ditentukan dengan persamaan berikut:

Perolehan $=\frac{m}{M} \times 100 \%$

dengan:

$\mathrm{m}=$ massa ekstrak setelah diuapkan sampai berat konstan, $\mathrm{g}$

$\mathrm{M}=$ massa serbuk kulit kacang yang digunakan pada proses ekstraksi, $g$

\subsection{Penentuan Total Phenolic Content}

Dalam penelitian ini, analisis Total Phenolic Content (TPC) dilakukan dengan menggunakan metode Folin-Ciocalteu Micro Test Method dengan reagen Folin-Ciocalteu yang absorbansinya diukur pada panjang gelombang 765 nm (Mongkolsilp dkk., 2004; Pourmorad dkk., 2006; Waterhouse, 1999). Reagen Folin-Ciocalteu terbuat dari campuran asam fosfowolframat $\left(\mathrm{H}_{3} \mathrm{PW}_{12} \mathrm{O}_{40}\right)$ dan asam fosfomolibdat $\left(\mathrm{H}_{3} \mathrm{PMo}_{12} \mathrm{O}_{40}\right)$. Reagen FolinCiocalteu akan mereduksi phospho-molibdic tungstate dan membentuk senyawa kompleks yang mengubah warna kuning menjadi biru (Mongkolsilp dkk., 2004). Kadar TPC pada 
ekstrak kulit kacang tanah dinyatakan sebagai ekuivalen asam galat atau Gallic Acid Equivalent (GAE), dimana GAE merupakan acuan umum untuk mengukur jumlah senyawa fenolik yang terdapat dalam suatu bahan (Mongkolsilp dkk., 2004). Asam galat banyak digunakan sebagai standar karena stabil dan dapat diperoleh dalam bentuk yang murni, serta harganya yang relatif murah dibandingkan dengan jenis senyawa standar yang lain (Sultana dkk., 2007).

Kurva baku sebagai standar untuk menentukan Total Phenolic Content (TPC) ekstrak dinyatakan dalam ekuivalen asam galat (GAE). Pertama-tama, dibuat larutan baku asam galat dengan konsentrasi 0,06, $0,05,0,04,0,03,0,02,0,01 \mathrm{mg} / \mathrm{mL}$. Masingmasing konsentrasi diambil $1 \mathrm{~mL}$ dan ditambahkan $5 \mathrm{~mL}$ reagen Folin-Ciocalteau dengan perbandingan $1: 10(\mathrm{v} / \mathrm{v})$ dan $4 \mathrm{~mL}$ Natrium karbonat 7,5\% untuk masing-masing konsentrasi. Larutan dibiarkan selama 30 menit pada suhu ruang lalu serapan diukur pada panjang gelombang $765 \mathrm{~nm}$ menggunakan spektrofotometer Shimadzu UV-Vis 1700.

Analisis sampel ekstrak dilakukan dengan cara mengambil sampel ekstrak sebanyak $2 \mathrm{mg}$ dan dilarutkan ke dalam $1 \mathrm{~mL}$ metanol dan dianalisis dengan perlakuan yang sama seperti larutan baku asam galat. TPC ekstrak dihitung dengan persamaan berikut:

$T P C=c . V / m$

dengan:

TPC $=$ Total Phenolics Content, mg GAE $/ \mathrm{g}$ ekstrak

$\mathrm{c}=$ konsentrasi asam galat, $\mathrm{mg} / \mathrm{L}$

$\mathrm{V}=$ volume larutan ekstrak $10 \mathrm{~mL}$

$\mathrm{m}=$ massa ekstrak, $\mathrm{g}$

\subsection{Uji Aktivitas Antioksidan}

Aktivitas antioksidan merupakan kemampuan antioksidan untuk menghambat aktivitas radikal bebas (Andayani dkk., 2008). Pengujian aktivitas antioksidan pada ekstrak kulit kacang tanah menggunakan metode serapan radikal bebas DPPH (2,2-diphenyl-1pikrylhydrazyl). Metode ini merupakan metode yang sederhana, mudah, dan menggunakan sampel dalam jumlah yang sedikit dengan waktu yang singkat (Yen dan Chen, 1995). Pengukuran aktivitas antioksidan sampel dilakukan pada panjang gelombang maksimum DPPH yaitu $520,55 \mathrm{~nm}$ dengan konsentrasi DPPH $50 \mu \mathrm{M}$. Adanya aktivitas antioksidan dari sampel menyebabkan perubahan warna pada larutan DPPH dalam metanol yang mula-mula berwarna ungu pekat menjadi kuning pucat (Molyneux, 2004) dengan reaksi seperti terlihat pada Gambar 2.

Reaksi tersebut merupakan mekanisme terjadinya proses penghambatan radikal bebas (DPPH) oleh senyawa antioksidan (AH). DPPH yang bersifat tidak stabil akan berikatan dengan atom $\mathrm{H}$ yang berasal dari antioksidan, baik itu antioksidan sintetis (TBHQ) maupun antioksidan alami (ekstrak kulit kacang tanah), sehingga DPPH akan berubah bentuk menjadi ikatan DPPH dengan atom $\mathrm{H}$ (DPPH-H) yang bersifat stabil. Antioksidan yang tidak berikatan bersifat lebih stabil walaupun telah kehilangan atom $\mathrm{H}$, dibandingkan dengan radikal bebas DPPH (Molyneux, 2004). Aktivitas antioksidan dinyatakan dalam scavenging activity atau aktivitas pengkhelatan (\%), yaitu kemampuan antioksidan untuk menghambat aktifitas radikal bebas. Nilai aktivitas pengkhelatan diperoleh dari perbedaan serapan antara serapan DPPH dengan serapan sampel yang diukur dengan spektrofotometer UV-VIS (Andayani dkk., 2008).<smiles>CCCCNc1c([N+](=O)[O-])cc([N+](=O)[O-])cc1[N+](=O)[O-]</smiles>

1,1-Difenil-2-pikrilhidrazil 1,1-Difenil-2-picrilhidrazin

Keterangan gambar: $\mathrm{AH}=$ antioksidan; $\mathrm{A}^{*}=$ turunan radikal antioksidan

Gambar 2. Mekanisme reaksi metode DPPH (Molyneux, 2004) 
Ekstrak kulit kacang tanah ditimbang sebanyak $1 \mathrm{mg}$ dan dilarutkan dalam $1 \mathrm{~mL}$ metanol. Larutan tersebut sebanyak $0,4 \mathrm{~mL}$ dipipet dan ditambahkan 7,6 mL larutan DPPH $50 \mu \mathrm{M}$. Campuran dihomogenkan dan dibiarkan selama 30 menit di tempat gelap. Serapan diukur pada panjang gelombang 520,55 nm dengan spektrofotometer Shimadzu UV-Vis 1700.

Aktivitas antioksidan sampel ditentukan menggunakan persamaan 3 .

Scavenging activity

$=\frac{\text { Abs. kontrol }- \text { Abs. sampel }}{\text { Abs. kontrol }} \times 100 \%$

dengan:

Abs. kontrol $=$ serapan radikal DPPH $50 \mu \mathrm{M}$ pada panjang gelombang 520,55 $\mathrm{nm}$.

Abs. sampel = serapan sampel dalam radikal DPPH $50 \mu \mathrm{M}$ pada panjang gelombang 520,55 $\mathrm{nm}$.

\section{Hasil dan Pembahasan}

Hasil penelitian tentang pengaruh suhu dan waktu ekstraksi terhadap perolehan ekstrak dan TPC dapat dilihat pada Gambar 3 dan Gambar 4. Pengaruh suhu dan waktu ekstraksi terhadap perolehan fenolik ditampilkan pada Gambar 5. Perolehan ekstrak ditentukan dengan persamaan (1). TPC (Total Phenolic Content) merupakan kadar senyawa fenolik dalam suatu bahan yang dinyatakan dalam g ekuivalen asam galat (GAE) per 100 g ekstrak, sedangkan fenolik perolehan fenolik adalah banyaknya senyawa yang terekstrak dinyatakan sebagai g GAE/ $100 \mathrm{~g}$ kulit kacang.

\subsection{Pengaruh Waktu Ekstraksi}

Gambar 3, 4, dan 5 menunjukkan perolehan dari senyawa fenolik yang dapat diekstrak dari kulit kacang tanah semakin banyak dengan bertambahnya waktu. Semakin lama waktu ekstraksi maka semakin banyak terjadi perpindahan massa dari kulit kacang tanah ke pelarut etanol. Perolehan ekstrak, TPC, dan perolehan fenolik meningkat perlahan pada awal proses ekstraksi sampai dengan waktu 45 menit. Dalam selang waktu berikutnya terlihat peningkatan perolehan yang lebih besar. Hal ini disebabkan karena pada awal proses ekstraksi, yaitu saat pertama kali kulit kacang tanah dikontakkan dengan pelarut etanol, kulit kacang tanah hanya mengekstrak senyawa fenolik yang terletak di bagian permukaan solid saja (Bernasconi, 1995). Dalam selang waktu berikutnya pelarut juga mengekstrak lebih banyak senyawa fenolik yang terdapat di bagian dalam solid sehingga perolehan dan TPC yang dihasilkan meningkat dan dapat mencapai perolehan maksimum.

Setelah waktu ekstraksi berjalan selama 105 menit, perolehan ekstrak, TPC, dan perolehan fenolik memperlihatkan fenomena yang berbeda pada suhu $30^{\circ} \mathrm{C}, 50$ ${ }^{\circ} \mathrm{C}$, dan $70{ }^{\circ} \mathrm{C}$. Pada suhu ekstraksi $30{ }^{\circ} \mathrm{C}$, perolehan ekstrak cenderung konstan setelah 105 menit. Hal ini dikarenakan pada saat itu

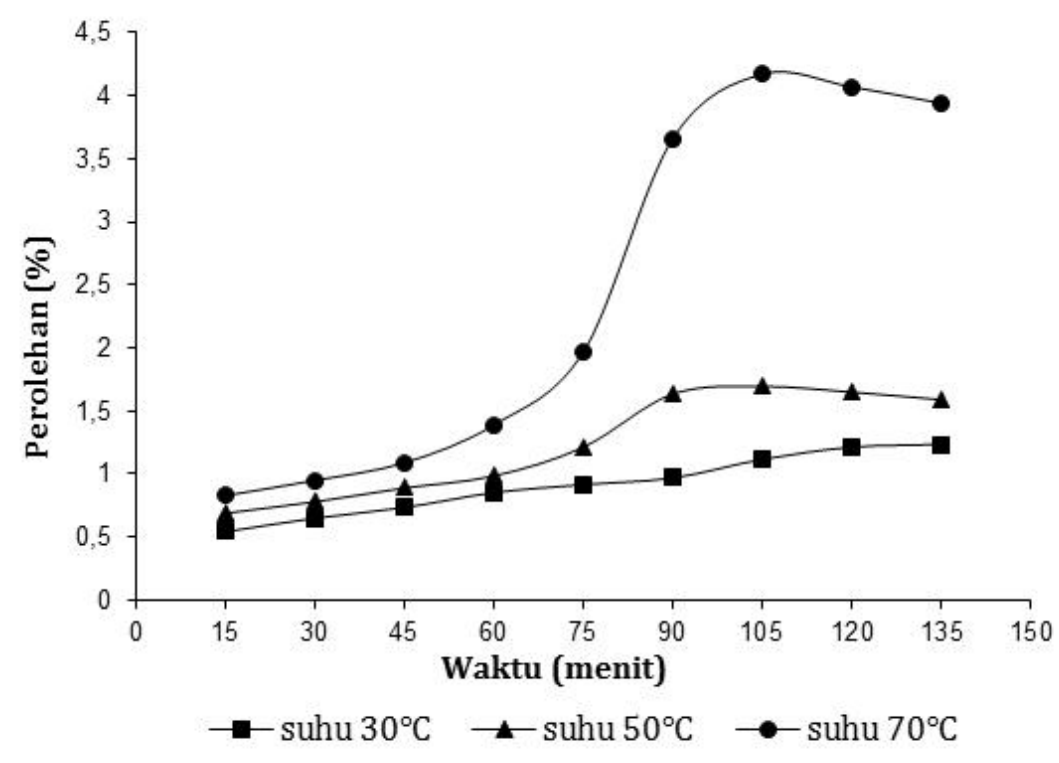

Gambar 3. Perolehan ekstrak kulit kacang tanah yang diperoleh pada berbagai waktu dan suhu ekstraksi 


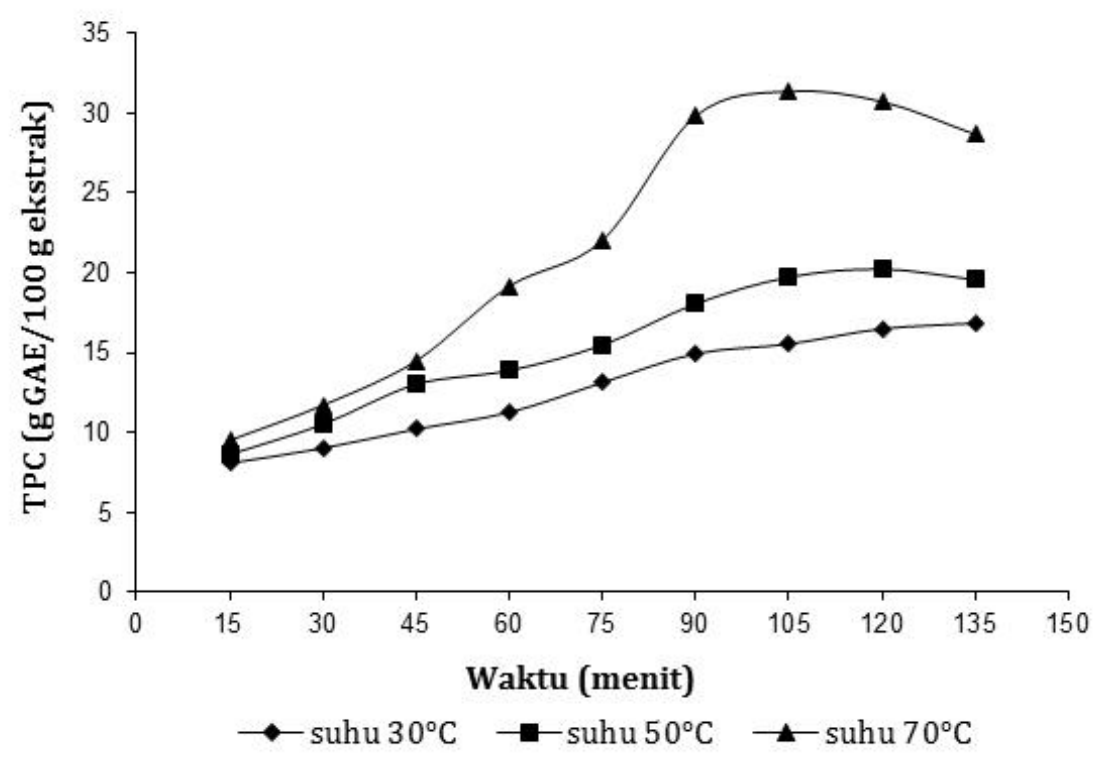

Gambar 4. TPC (dalam g GAE/100 g ekstrak) dalam ekstrak kulit kacang tanah pada berbagai suhu dan waktu ekstraksi

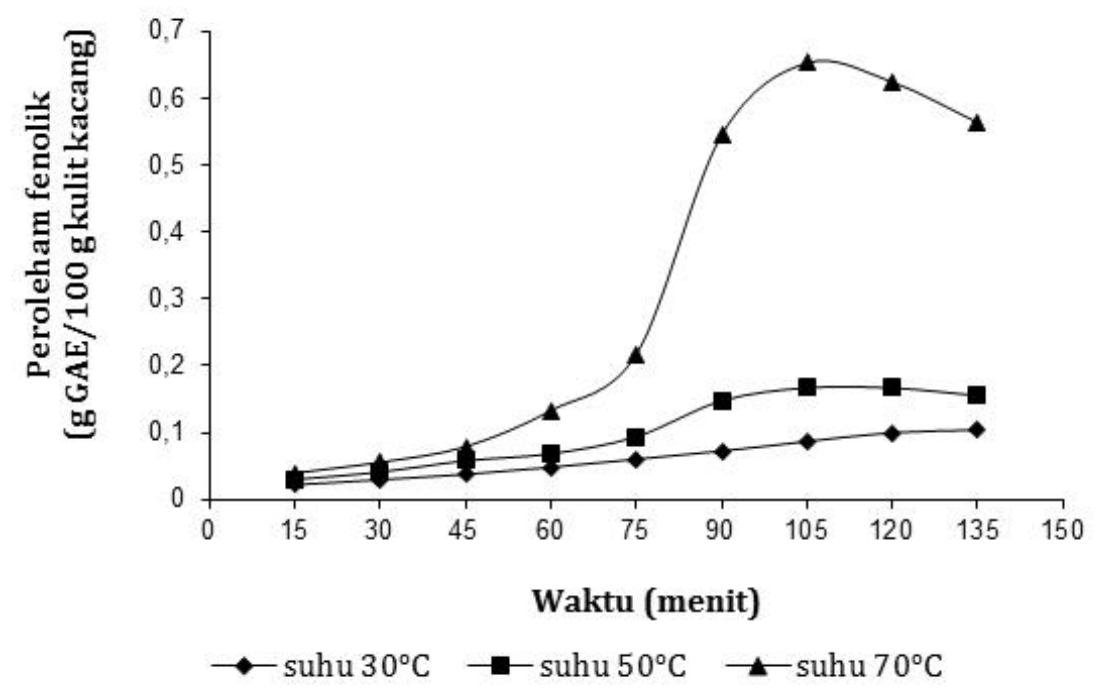

Gambar 5. Perolehan fenolik (dalam g GAE/100 g kulit kacang) yang diperoleh pada berbagai suhu dan waktu ekstraksi

sudah mencapai keadaan equilibrium sehingga senyawa fenolik yang terdapat di permukaan dan di bagian dalam solid sudah tidak dapat terekstrak lagi (Bernasconi, 1995). Pada suhu yang lebih tinggi, yaitu $50{ }^{\circ} \mathrm{C}$ dan $70{ }^{\circ} \mathrm{C}$, setelah 2 jam terjadi penurunan perolehan ekstrak, TPC dan perolehan senyawa fenolik. Hal ini dikarenakan pada waktu ekstraksi yang lama dan pada suhu yang semakin tinggi, senyawa fenolik yang terekstrak dari kulit kacang dapat terdegradasi oleh cahaya dan oksigen (Hismath dkk., 2011)

\subsection{Pengaruh Suhu Ekstraksi}

Gambar 3, 4, dan 5 menunjukkan bahwa pada semua waktu ekstraksi dalam kisaran $30{ }^{\circ} \mathrm{C}$ hingga $70{ }^{\circ} \mathrm{C}$, perolehan ekstrak, TPC, dan perolehan senyawa fenolik semakin meningkat seiring dengan kenaikan suhu ekstraksi. Pada suhu yang semakin tinggi kelarutan senyawa fenolik dalam pelarut, dan koefisien difusi solut dalam pelarut semakin meningkat, sedangkan viskositas pelarut akan berkurang sehingga dapat memudahkan peristiwa perpindahan massa (Santos-Buelga 
dan Williamson, 2003). Selain itu, peningkatan suhu juga menyebabkan jaringan dinding sel partikel solid lebih lunak sehingga solut lebih mudah terekstrak.

\subsection{Kondisi Optimum dengan Perolehan Fenolik Terbesar}

Dalam penelitian ini, kondisi ekstraksi yang menghasilkan perolehan ekstrak terbesar $(4,17 \%)$, TPC terbesar $(15,669 \mathrm{~g}$ GAE/100 g ekstrak) dan perolehan senyawa fenolik terbesar $(0,6534 \mathrm{~g}$ GAE/100 g kulit kacang tanah) diperoleh pada kondisi suhu ekstraksi $70{ }^{\circ} \mathrm{C}$ dan waktu ekstraksi 105 menit. Sebagai pembanding, ekstraksi kulit kacang tanah dengan metode soxhletasi menghasilkan 0,7142 g GAE/100 g kulit kacang tanah. Hal ini menunjukkan bahwa ekstraksi pada kondisi perolehan senyawa fenolik terbesar sudah mampu mengekstrak 91,48\% senyawa fenolik dalam bahan baku kulit kacang bila diasumsikan ekstraksi dengan soxhlet dapat mengekstrak seluruh senyawa fenolik dalam kulit kacang tanah.

\subsection{Aktivitas Antioksidan pada Perolehan Senyawa Fenolik terbesar pada Berbagai Variasi Suhu}

Aktivitas antioksidan dari sampel ekstrak kulit kacang tanah dinyatakan dalam persentase aktivitas pengkhelatan (scavenging activity) terhadap radikal DPPH yang dihitung dengan persamaan (3). Perbandingan aktivitas antioksidan antara antioksidan alami (ekstrak kulit kacang tanah) dan antioksidan sintetis (TBHQ) ditunjukkan pada Gambar 6 . Ekstrak kulit kacang tanah yang diuji aktivitasnya adalah ekstrak dengan perolehan fenolik terbesar yang diperoleh pada waktu 105 menit pada masing-masing suhu ekstraksi $\left(30,50\right.$, dan $\left.70{ }^{\circ} \mathrm{C}\right)$.

Pada Gambar 6 terlihat bahwa TBHQ memiliki aktivitas pengkhelatan paling besar, yaitu sebesar 98,38\%. Semakin besar aktivitas pengkhelatan, semakin besar pula kemampuan menangkap radikal bebas. Senyawa fenolik merupakan senyawa antioksidan yang berfungsi untuk mengurangi radikal bebas (Uma dkk., 2010). Dari gambar tersebut juga diketahui bahwa aktivitas pengkhelatan ekstrak kulit kacang tanah masih lebih kecil dibandingkan dengan aktivitas pengkhelatan antioksidan sintetis TBHQ. Hal ini dapat disebabkan karena TPC ekstrak lebih kecil daripada TPC pada TBHQ seperti terlihat pada Tabel 1 . aktivitas pengkhelatan meningkat seiring dengan makin besarnya TPC ekstrak.

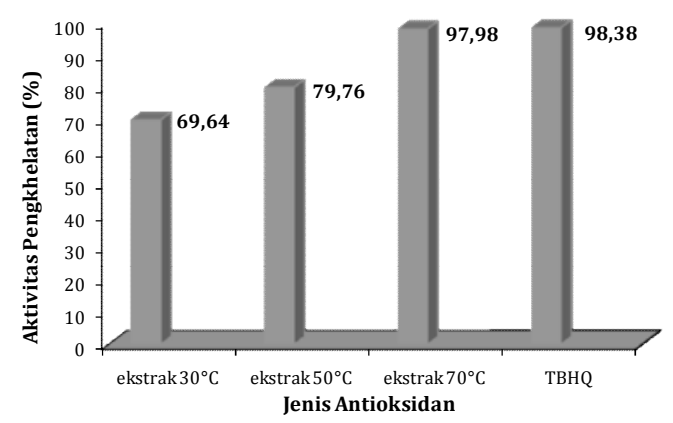

Gambar 6. Aktivitas antioksidan ekstrak kulit kacang tanah dan TBHQ

Tabel 1. Perbandingan TPC dan Aktivitas Pengkhelatan Antioksidan Alami Ekstrak Kulit Kacang dengan Antioksidan Sintetis TBHO

\begin{tabular}{lcc}
\hline Antioksidan & $\begin{array}{c}\text { TPC } \\
\text { (g GAE/100 g } \\
\text { ekstrak) }\end{array}$ & $\begin{array}{c}\text { Aktivitas } \\
\text { Pengkhelatan } \\
\text { (\%) }\end{array}$ \\
\hline $\begin{array}{l}\text { Ekstrak } 30^{\circ} \mathrm{C} \\
105 \text { menit }\end{array}$ & 7,7654 & 69,64 \\
$\begin{array}{l}\text { Ekstrak } 50^{\circ} \mathrm{C} \\
105 \text { menit }\end{array}$ & 9,8566 & 79,76 \\
$\begin{array}{l}\text { Ekstrak } 70^{\circ} \mathrm{C} \\
105 \text { menit }\end{array}$ & 15,669 & 97,98 \\
TBHQ & 19,7582 & 98,38 \\
\hline
\end{tabular}

\section{Kesimpulan}

Dari penelitian ekstraksi senyawa fenolik dari kulit kacang tanah pada kisaran suhu ekstraksi $30{ }^{\circ} \mathrm{C}, 50{ }^{\circ} \mathrm{C}$, dan $70{ }^{\circ} \mathrm{C}$ serta waktu ekstraksi 15-135 menit diperoleh kesimpulan bahwa semakin tinggi suhu dan semakin lama waktu ekstraksi maka perolehan ekstrak, kadar senyawa fenolik, dan perolehan fenolik yang dihasilkan semakin tinggi sampai pada waktu tertentu, kemudian mengalami penurunan. Suhu ekstraksi $70{ }^{\circ} \mathrm{C}$ dan waktu ekstraksi 105 menit merupakan suhu dan waktu ekstraksi optimum yang menghasilkan perolehan senyawa fenolik terbesar yaitu 0,6534 g GAE/100 g kulit kacang.

\section{Daftar Pustaka}

Andayani, R.; Maimunah; Lisawati, Y., Penentuan aktivitas antioksidan, kadar fenolat total, dan likopen pada buah tomat (Solanum lycopersicum L), Sains dan Teknologi Farmasi, 2008, 13(1), 31-37.

AOACS, Official Methods and Recommended Practices of the American Oil Chemical 
Society. Method 976.05 (moisture content analysis) dan 923.03 (ash content analysis), 2000, Champaign, IL, USA: AOCS Press.

Bernasconi, G., Teknologi Kimia (Bagian 2); PT Pradnya Paramita: Jakarta, 1995.

Dengi, Y. K.; Mulyandasari, V., Pemanfaatan Limbah Tongkol Jagung sebagai Antioksidan Alami untuk Minyak Goreng Kelapa Sawit, Skripsi S1, Universitas Katolik Widya Mandala, 2009.

Halliwell, B.; Gutteridge, J. M. C., Free Radical in Biology and Medicine; Oxford University Press: New York, 2000.

Hismath, I.; Wan Aida, W. M.; Ho, C. W., Optimization of extraction conditions for phenolic compounds from neem (Azadirachta indica) leaves, International Food Research Journal, 2011, 18(3), 931-939.

Iqbal, S.; Bhanger, M. I.; Anwar, F., Antioxidant properties and components of some comercially available varieties of rice bran in Pakistan, Food Chemistry, 2005, 93(2), 265272.

Kikuzaki, H.; Hisamoto, M.; Hirose, K.; Akiyama, Kayo.; Taniguchi, H., Antioxidant properties of ferulic acid and its related compounds, Journal of Agricultural and Food Chemistry, 2002, 50(7), 2161-2168.

Molyneux, P., The use of the stable free radical diphenyl picrylhydrazyl (DPPH) for estimating antioxidant activity, Journal of Science and Technology, 2004, 26(2), 211-219.

Mongkolsilp, S.; Pongbupakit, I.; Sae-Lee, N.; Sitthithaworn, W., Radical scavenging activity and total phenolic content of medical plants used in primary health care, Journal of Pharmacy and Science, 2004, 9(1), 32-35.
Pokorny, J.; Yanishlieva, N.; Gordon, M., Antioxidants in Food: Practical Applications; CRC Press: Boca Raton, 2001.

Pourmorad, F.; Hossenimehr, S. J.; Shahabimajd, N., Antoxidant activity, phenol and flavonoid contents of some selected iranian medicinal plants, African Journal of Biotechnology, 2006, 5(11), 1142-1145.

Santos-Buelga, C.; Williamson, G., Methods in Polyphenol Analysis; Royal Society of Chemistry: Great Britain, 2003.

Sultana, B.; Anwar, F.; Przybylski, R., Antioxidant potential of corncob extracts for stabilization of corn oil subjected to microwave heating, Food Chemistry, 2007, 104(3), 997-1005.

Uma, D. B.; Ho, C. W.; Wan Aida, W. M., Optimization of extraction parameters of total phenolic compounds from henna (Lawsonia inermis) leaves, Sains Malaysiana, 2010, 39(1), 119-128.

Waterhouse, A., Folin - Ciocalteu Micro Method For Total Phenol In Wine, Department of Viticulture \& Enology University Of California, Davis, 1999.

Wee, J. H.; Moon, J. H.; Eun, J. B.; Chung, J. H.; Kim, Y. G.; Park, K. H., Isolation and identification of antioxidants from peanut shells and the relationship between structure and antioxidants activity, Food Science and Biotechnology, 2007, 16(1), 116-122.

Yen, G. C.; Chen, H. Y., Antioxidant activity of various tea extracts in relation to their antimutagenicity, Journal of Agriculture and Food Chemistry, 1995, 43(1), 27-32. 